\title{
Effect of exogenous phytase on egg production and egg quality of spent hen
}

\author{
M. K. Bashar ${ }^{1 *}$, M. A. R. Howlider ${ }^{2}$ and S. M. Bulbul ${ }^{2}$ \\ ${ }^{1}$ Bangladesh Livestock Research Institute, Savar, Dhaka-1341, Bangladesh. ${ }^{2}$ Department of Poultry \\ Science, Bangladesh Agricultural University, Mymensingh-2202, Bangladesh
}

\begin{abstract}
The present study determined, assessed and quantified the exogenous phytase on egg production and egg quality of spent hens. Ninety laying hens (ISA- Brown) received iso-energetic and iso-nitrogenous diet supplemented with $0,0.05,0.1,0.15$ and $0.2 \%$ phytase and reared in cages. Each layer was fed $120 \mathrm{~g}$ feed/day from 90 to 100 weeks of age. At the inception of the study the spent hen at the age of 90 weeks had an average egg production $65.21 \%$. Phytase addition in diet increased ( $\mathrm{p}<0.05$ ) egg production (7.67, 12.17, 12.04 and $15.87 \%$ higher than control group), egg mass output $(5.5,9.34,7.65$ and $12.72 \%$ higher than that of control) and feed conversion, but it did not alter shell weight, shell thickness. shape index, albumen index, Haugh unit, per cent yolk and yolk color. It was concluded that reduced egg production of spent hen at older ages to some extent might have a relationship to decreased availability of phosphorus. The decreased egg production in hens at older ages could be corrected by adding appropriate phytase level in the diet. Thus, it may be possible to extend and prolonged productive life of spent hens by supplying exogenous phytase in diet. However, the effect of availability of phosphorus on egg production using larger population for a longer period may be performed to confirm the findings of the current study.
\end{abstract}

(Key words: Phytase, egg production, egg quality, prolong the egg laying period)

\section{Introduction}

Commercial layer production in Bangladesh has gained a momentum during 1980 and 1990 and it took the industrial shape (Chowdhury, 2011) thus we are producing 6600 million pieces of egg representing 60 to $70 \%$ of country's total poultry egg production. In Bangladesh, commercial layer farming is increasing rapidly during the last three decades due to increased demand of eggs. Poultry, specially, leading species; chicken lay eggs in a specified and peculiar fashion; egg production sharply increase to peak from start and then gradually declined. The success of layer farm depends on the level of egg production. The layer performance depends on genetic background, nutrition, physiology, environment and management (Banerjee, 1992). A laying hen produce eggs for a number of years, but profitable rearing is obtained up to the age of $72-76$ weeks. Akbas et al. (1977) reported decline in egg production after peak with the advance of age of the hens. As the age increased, egg production and egg

*Corresponding author: mkbashar@blri.gov.bd

Bang. J. Livs. Res. Vol. 20 (1 \& 2), 2013: P. 68-76 ISSN 1022-3851 
quality sharply increased, but after the period of peak production at about 32 weeks, egg production and egg quality gradually declined. However, the length of laying period is not fixed. It depends on egg production level of the flock. At older ages, both egg production and dietary phosphorus (P) utilization are depressed (Al-Batshan et al., 1994). It is not known whether diminished egg yield and inferior egg quality in older hens could be attributed to decrease availability of $P$. It is also not clear whether such an age related diminished egg production and egg quality could be corrected by supplying exogenous phytase. Use of vegetation base formulated economic diet for poultry contain a variable concentration (about 50-80 per cent) of $\mathrm{P}$ in the form of insoluble complex, phytic acid or phytate, is not available to chicken (Eeckhout and De Paepe, 1994). P is one of the major mineral elements required to hens and plays a major role in several metabolic processes. $\mathrm{P}$ and $\mathrm{Ca}$ are important for layers (Roland and Gordon, 1996) to ensure adequate egg production and eggshell quality. Phytase is hydrolyzes phytic acid to inositol and phosphoric acid (Liu et al., 1998 and Leske and Coon, 1999). making $\mathbf{P}$ availability and many other nutrients to poultry. Some cereals contain endogenous phytase activity (Eeckhout and De Paepe, 1994) and there may be phytase activity in the small intestine of chicken (Maenz and Classen, 1998). Researchers attempted to increase P utilization through supplementation of microbial phytase for incorporation into poultry feed (Cromwell et al., 1995). Hydrolyze phytic acid in plant materials; thereby release inorganic $P$ available for absorption in the digestive tract of fowl. The use of phytase in layer diets also reduces the requirements for inorganic $P$ (Gordon and Roland, 1997; Carlos and Edwards, 1998 and Um and Paik, 1999) thereby reducing costs associated with inorganic P. Boling et al., (2000) rotted the effects of dietary available phosphorus (AP) and exogenous phytase on performance of young and older laying hens. They concluded that maizesoybean meal diets containing $0.15 \% \mathrm{P}$ (159 $\mathrm{mg} \mathrm{AP} /$ day) or containing $0.1 \% \mathrm{AP}+300$ units of phytase/kg (108mg AP/day) supported optimal egg production from 20 to 70 weeks of age. A number of researches used different exogenous phytase in egg type chicken at younger age. Researchers are scanty with regard to relations between $P$ availability and egg production of hen at older ages. Present study assessed, quantified and compared the egg production and egg quality of older layers by adding dietary exogenous phase. $\mathrm{Ca}$ and $\mathrm{P}$ have a significant role in the growth and development of skeleton and other exoskeleton. In general blood is not a good reserve of $\mathrm{Ca}$ and $\mathrm{P}$. Therefore, source of $\mathrm{Ca}$ and $\mathrm{P}$ must be maintained during whole life span without break. Hence current study was assessed and compared the egg production and egg quality of older ages as influenced by exogenous phase.

\section{Materials and Methods}

The experiment was conducted for a period of 70 days from 26 September to 06 December, 2011 at Bangladesh Agricultural 
University (BAU) Poultry Farm and egg quality determination was performed in the Poultry Science Laboratory in the Department of Poultry Science. Phytase was collected from the dealer of Renata pharmaceuticals. A total of ninety, 90 weeks old healthy ISA- Brown layers were collected from BAU Poultry Farm and reared in cages for a period of 10 weeks. Six hens were accommodated in group cage measuring $13 \mathrm{~cm} \times 9 \mathrm{~cm} \times 16 \mathrm{~cm}$ of length, width and height respectively. Six hens kept in each cage were considered as an experimental unit (replication). The phytase was mixed with small amount of feed and then thoroughly mixed with total amount of feed according to phytase level. The basal diet was formulated without supplementation of Rena-Phytase-400. However, in other diets phytase was added at $0.05 \%, 0.1 \%$ $0.15 \%$ and $0.2 \%$ (Rena-Phytase- 400 ). Five diets were stored (for 7 days) separately in 5 gunny bags according to phytase level for further use. Each hen was allocated $120 \mathrm{~g}$ feed/day. Fresh clean drinking water was made available at all times. During the whole experimental period, all hens were exposed to a 16 hours continuous photoperiod (natural light + artificial light) in an open sided house. Body weight change, egg production, egg mass production, egg weight and feed conversion ratio were calculated. One egg from each replication of four treatments was considered during the last week of experimental period to determine the egg quality characteristics. Each egg for quality determination was cleaned by wet cloth and then numbered by $4 \mathrm{~B}$ wooden pencil immediately after collection from pens according to phytase level. All data, either measured or calculated were collected for a Completely Randomized Design (CRD) with three replications for each phytase level. Analysis of variance was performed to compare all the variables among the combinations of phytase levels and replication. Significant differences were isolated by calculating Least Significant Difference (LSD). The data was analyzed by using SPSS-17.0 statistical software program.

\section{Results}

\section{Egg Production}

Exogenous phytase can be added to diets to hydrolyze phytate in the digestive tract. increasing the availability of phytate $P$ and decreasing dietary need of inorganic $P$. Phytase also improves the utilization of other minerals that are bound to plant phytate.

Data in Table 1 showed that egg production (\%), egg mass production and feed conversion were significantly differed ( $p>$ 0.01 ). There were tendency of linear increase of those three variables with the increase of dietary phytase level. Dietary Phytase did not differ among the diets fortified with different levels of dietary phytase.

Table 1 also indicated that there were no differences in final live weight, feed intake and egg weight which could be attributed to the dietary levels of phytase. However, the Fig. 01 impressed that final live weight tented to be increased between 0 to $0.15 \%$ but thereafter diminish at $0.2 \%$ dietary 
Table 1. Egg production of spent hens on different levels of dietary exogenous phytase

\begin{tabular}{|c|c|c|c|c|c|c|c|}
\hline \multirow[b]{2}{*}{ Parameters } & \multicolumn{5}{|c|}{ Dietary Phytase level (\%) } & \multicolumn{2}{|c|}{ Significance } \\
\hline & Control & 0.05 & 0.1 & 0.15 & 0.2 & $\begin{array}{l}\text { Over } \\
\text { all SE }\end{array}$ & Level \\
\hline $\begin{array}{l}\text { Initial live weight } \\
\text { (g/hen) }\end{array}$ & $1903.3 \pm 19.2$ & $1925.0 \pm 38.2$ & $1953.3 \pm 39.4$ & $1958.3 \pm 50.7$ & $1925 \pm 38.2$ & 15.5 & NS \\
\hline $\begin{array}{l}\text { Final live weight } \\
\text { (g/hen) }\end{array}$ & $1981.7 \pm 4.4$ & $2010.0 \pm 42.7$ & $2046.7 \pm 39.2$ & $2052.7 \pm 52.6$ & $2018 \pm 38.2$ & 16.3 & NS \\
\hline $\begin{array}{l}\text { Live weight } \\
\text { gain(gm.)/day }\end{array}$ & $1.13 \pm 0.32$ & $1.23 \pm 30.1$ & $1.33 \pm 0.06$ & $1.37 \pm 0.03$ & $1.36 \pm 0.03$ & 0.06 & NS \\
\hline Egg Production (\%) & $65.21^{c} \pm 1.6$ & $72.89^{b} \pm 1,2$ & $77.38^{\mathrm{ab}} \pm 2.2$ & $77.25^{\mathrm{ab}} \pm 1.0$ & $81.08^{\mathrm{a}} \pm 3.0$ & 1.63 & ** \\
\hline $\begin{array}{l}\text { Egg mass Production } \\
\text { (g/Hen/day) }\end{array}$ & $39.8^{c} \pm 1.8$ & $45.3^{b}+1.5$ & $49.1^{\mathrm{ab}_{ \pm 1.3}}$ & $47.4^{\mathrm{b}} \pm 1.5$ & $52.5^{a} \pm 1.7$ & 1.3 & *** \\
\hline $\begin{array}{l}\text { FCR } \\
\text { (Feed intake/Egg } \\
\text { mass) }\end{array}$ & $3.03^{\mathrm{a}} \pm 0.13$ & $2.65^{b} \pm 0.09$ & $2.45^{b_{ \pm}} \pm 0.06$ & $2.53^{b c} \pm 0.08$ & $2.29^{c} \pm 0.08$ & 0.07 & ** \\
\hline Egg weight $(g / \mathrm{Eg})$ & $61.0 \pm 1.3$ & $62.1 \div 1.1$ & $63.5 \pm 0.92$ & $61.5 \pm 2.6$ & $64.8 \pm 0.4$ & 0.67 & NS \\
\hline
\end{tabular}

Figures with different superscript in the same row differ significantly at $* *=\mathrm{P}<0.01$ level; NS= Non significant

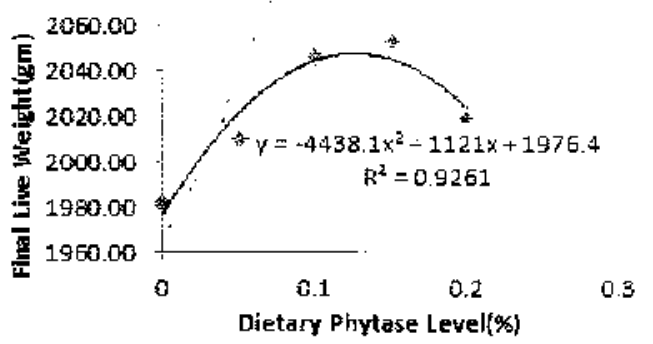

Fig-1 The relationship between final live weight (g/hen) and dietary phrtase level (\%)

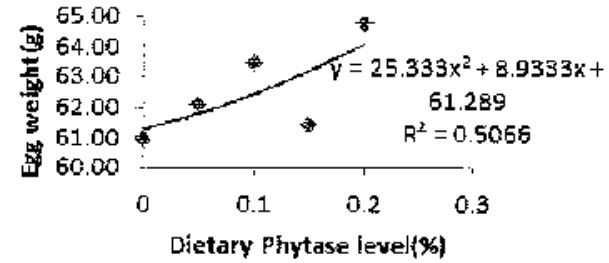

Fig-2 The relationship between Egg weight (g) and dietary phytase level $|\%|$ phytase. Egg weight did not differ among the levels of dietary phytase but the Fig. 02 implies that egg weight tented to be increased with the increase of phytase level up to $0.1 \%$, depleted at $0.15 \%$ and again repleted at $0.20 \%$ dietary phytase.

\section{Egg Quality}

The information catalogued in Table 2 impressed that dietary phytase had insignificance relations with egg quality parameters ( $p>0.05$ ). However the both signal that those table 02 variables; shell weight and shell percent tented to be increased with the increased of dietary phytase level ( $p>0.05$ ) and also indicated that there was a positive relation between shell weight and shell per cent. Increasing phytase level tents to be increased $(p>0.05)$ shell thickness. On the other hand dietary phytase level at higher doses detriment the Shape index. It is evident from that increasing phytase level tented to be diminished albumen index between 0 to $0.1 \%$, 
which was again, replied with the increase of phytase up to $0.2 \%$ dietary phytase. The yolk indices were almost similar at $0,0.1$ and $0.2 \%$ but it was drastically diminished at $0.05 \%$ level of dietary phytase. The yolk per cent and Haugh unit were similar and highest $0,0.1$ and 0.2 , intermediate on 0.1 and lowest at $0.05 \%$ of dietary phytase indicating an irregular trend. All the dietary phytase levels hindred the yolk color index with the increase of phytase level.

\section{Discussion}

Almost linear increased in egg production and egg mass production obtained (Table 1) impressed that the poorer availability of phosphorus may be an important determinant of egg production of commercial layer at older ages. Moreover, it implies that, age related declined egg production could be corrected by using exogenous phytase at optimum doses. Such a result is supported by some other investigates (Lucky, 2010; Hughes et al., 2008; Augspurger et al., 2007; Lim et al. 2003 and Boling et al., 2000). Lucky (2010) also noted, increased egg production and egg mass production for supplementation of dietary phytase at $0,0.05,0.1$ and $0.15 \%$. The respective increased of egg production were $11.86,22.2$ and $24.58 \%$ against those levels of exogenous phytase coincide with the results of current study. Such a coincidence of the result obtained agrees with Lucky (2010). The data also impressed that; increased productivity of layer spent hens may be obtained irrespective of group size. Providing phytase in the diet at 0.05 , $0.10,0.15$ and $0.2 \%$ increased egg production by $7.67,12.17,12.04$ and 15.87 $\%$ respectively. Availability and retention of $\mathrm{P}$ and $\mathrm{Ca}$ are decreased in hens at older ages (Al-Batshan et al., 1994). On the other hand,

Table 2. Egg quality of spent hens (76-82) weeks on different level of exogenous phytase

\begin{tabular}{lcccccccc}
\hline \multirow{2}{*}{ Variable } & \multicolumn{9}{c}{ Dietary } & Phytase level (\%) & \multirow{2}{*}{ SED } & \multirow{2}{*}{ Significance } \\
\cline { 2 - 6 } & 0 & 0.05 & 0.1 & 0.15 & 0.2 & & \\
\cline { 2 - 6 } Shell Weight(g/egg) & 6.85 & 6.96 & 7.12 & 7.30 & 7.23 & 0.341 & NS \\
Shell (per cent) & 0.35 & 0.35 & 0.35 & 0.36 & 0.36 & 0.019 & NS \\
Shell thickness (mm) & 0.39 & 0.40 & 0.39 & 0.42 & 0.43 & 0.027 & NS \\
Shape Index & 74.28 & 75.03 & 71.34 & 69.29 & 69.77 & 2.089 & NS \\
Albumen Index & 0.06 & 0.06 & 0.06 & 0.064 & 0.07 & 0.008 & NS \\
Yolk Index & 0.45 & 0.44 & 0.45 & 0.45 & 0.45 & 0.012 & NS \\
Yolk percent & 0.90 & 0.88 & 0.89 & 0.88 & 0.89 & 0.038 & NS \\
Haugh Unit & 72.30 & 68.20 & 69.80 & 72.30 & 71.50 & 5.330 & NS \\
Yolk color Index & 06.33 & 6.00 & 6.00 & 6.00 & 6.00 & 1.116 & NS \\
\hline
\end{tabular}

\footnotetext{
${ }^{+} \mathrm{NS}, \mathrm{p}>0.05$; all SED's are against 10 error degrees of freedom
} 
egg production is also depleted with the advance of age (Banerjee, 1992). Such results imply that there may be a relation between decreased availability of $P$ and egg production of hens at older ages. The remarkably higher egg production on different doses of exogenous phytase gave an impression that the economic productive life and egg production of hens can be extended and prolonged by increased $P$ availability. The possible relation of phytase, availability of $\mathrm{Ca}$ and $\mathrm{P}$ and egg production has been supported by Francesch et al., (2005), Cabuk et al., (2004), Um and Paik (1999), Gordon and Roland (1998). Increased feed conversion of hens at increasing level of phytase obtained (Table 1) is supported by various researchers. Francesch et:al., (2005) reported that supplementation of microbial dietary phytase $(0,300$ and $600 \mathrm{Ukg}-1)$ improved egg production, egg weight and feed conversion in layer hens. Phytase supplementation with $3.0 \mathrm{~g}$ available $\mathrm{P} / \mathrm{kg}$ diet improved $(\mathrm{P}<0.05)$ feed conversion. Jalal and Scheideler (2001) also reported that phytase supplementation $(p<0.05)$ improved feed conversion of laying hens. Contradicting current results, Van Der Klis et al., (1997) and Um and Paik (1999) reported that phytase supplementation to the diets containing 3.3 and $3.7 \mathrm{~g}$ available phosphorus/kg had no beneficial effect on feed conversion. Similar egg weight noted on varying levels of phytase supplementation in the current study (Table 1) is getting support from Liu et al. (2007), Carlos and Edwards (1998), Jalal and
Scheideler (2001). However, several previous reports demonstrated that supplementation of phytase generally enhanced egg production of chicken coupled with increased egg weight (Um and Paik, 1999 and Silversides et al. 2006). In this study, egg shell per cent and egg shell thickness increased with the increasing level phytase, althrough no significant differences were found (Table 2). These results are in agreement with those of Nezhad and Kandi (2008), Panda et al., (2005), Lim et al., (2003) and Roland et al., (2003). Nezhad and Kandi (2008) also reported that phytase addition in low available $P$ diets increased eggshell weight and eggshell thickness. Panda et al., (2005) reported that the addition of phytase to corn and soybean based diets containing $0.12 \%$ non-phytate $\mathrm{P}$ improved the egg production and eggshell quality of layers to the level of those fed diets containing 0.18 to $0.30 \%$ NPN (Non Protein Nitrogen). The increased shell thickness was not reflected as shell hardness and the exact reason of hardness is unknown. The result obtained (Table 2) is in agreement with the report of Um and Paik (1999). They suggested the association between eggshell hardness and thickness was not inevitable. Shell thickness mainly depends on $C a$ aggregations as calcium carbonate, whereas shell hardness mainly depends on the texture, composed of $\mathrm{Ca}$ carbonate, organic materials, and trace minerals (Chowdhury and Smith, 2002; Mabe et al., 2003 and Nakano et al, 2003). There were no differences $(p>0.05)$ in shape index, albumen index, yolk index, per cent yolk, 
yolk color and $\mathrm{HU}$ among the levels of phytase in the current study (Table 2) is supported by Park et al., (2009) and Um and Paik (1999).

\section{Conclusion}

In conclusion, increased egg production with the addition of phytase signifies that decreased egg production at older ages may be the function of phosphorus unavailability. It may be possible to extend the production life of hens by supplementation of exogenous phytase in the diet of older hens. This study using limited number of layers signals the possibility to up hold the desirable and profitable egg production by supplementing phytase in diet. Studies using larger layer population of chicken in cluster could be conducted to confirm the result of this study.

\section{Acknowledgement}

The authors gratefully acknowledge Department of Poultry Science at BAU, Mymensingh from which data for this study were obtained.

\section{References}

Akbas, Y. Alton O. J. and Kocak, C. 1977. Effect of hens age on external and internal egg quality traits. Poultry Abstracts, 23: 7.

Al-Batshan, H. A. Scheideler, S. E. Black, B. L. Garlich, J. D. and Anderson. K. E. 1994. Duodenal calcium uptake, femur ash, and eggshell quality decline with age and increase following molt. Poultry Science, 73: 1590-1596.
Augspurger, N.R., Webel D.M. and Baker, D.H. 2007. An Escherichia coli phytase expressed in yeast effectively replaces inorganic phosphorus for finishing pigs and laying hens. Journal of Animal Science, 85: 1192-1 198.

Banerjee, G.C. 1992. Egg producing carrier of a laying hen. Poultry, 45-46.

Boling, S.D. Douglas, M.W., Johnson, M.L. Wang, X. Parsons, C.M. Koelkebeck, K.W. and Zimmerman. R. A. 2000. The effects of dietary available phosphorus levels and phytase on performance of young and older laying hens. Poultry Science, 79: 224-230.

Cabuk, M., Bozkurt, M. Kyrkpy, F. and Ozkul, H. 2004. Effect of phytase supplementation of diets with different levels of phosphorus on performance and egg quality of laying hens in hot climatic conditions. South African Journal of Animal Science, 34: 13-17.

Carlos, A.B. and Edwards, H.M. 1998. The effect of 1.25-dibydroxycholicalciferol and phytase on the natural phytate phosphorus utilization by laying hens. Poultry Science, 77: 850-858.

Chowdhury, S.R. and. Smith, T.K. 2002. Dietary interaction of 1,4-diaminobutane (putrescine) and calcium on eggshell quality and performance in laying hens. Poultry Science, 81: 84-91.

Chowdhury, S.D. 2011. Commercial Poultry Farming in Bangladesh: The Rolling tears of farmers and its consequences. Seventh International Poultry show and seminar. 01-01.

Cromwell, G.L., Coffey, R.D., Parker, G.R., Monegue J.J. and Randolph, J.H. 1995. Efficacy of a recombinant-derived phytase in improving the bioavailability of phosphorus in corn-soybean diets for pigs. Journal of Animal Science, 73: 2000-2008. 
Eeckhout, W. and De Paepe, M. 1994. Total phosphorus, phytate phosphorus and phytase activity in plant feedstuffs. Animal Feed Science and Technology, 47: 19-29.

Francesch, M., Broz, J. and Brufau, J. 2005. Effects of an experimental phytase on performance, egg quality, tibia ash content and phosphorus bioavailability in laying hens fed on maize- or barley-based diets. British Poultry Science 46: 340-348.

Gordon, R.W. and Roland, S.R. 1998. Influence of supplemental on calcium and phosphorus utilization in laying hens. Poultry Science, 77 . 290-294

Gordon, R.W. and Roland, Sr. D.A. 1997. Performance of commercial laying hens fed various phosphorus levels, with and without supplemental phytase. Poultry Science, 76: 1172- 1177.

Hughes, A.L., Dahiya, J.P., Wyatt C.L. and Classen, H,L. 2008. The efficacy of quantum phytase in a forty-week production trial using white leghorn laying hens fed corn-soybean meal-based diets. Poultry Science, 87: 1156-1161.

Jalal, M.A. and Scheideler, S.E. 2001. Effect of supplementation of two different sources of phytase on egg production parameters in laying hens and nutrient digestibility. Poultry Science, 80: 1463-1471.

Leske, N.J.K.L. and Coon, C.N. 1999. A bioassay to determine the effect of phytase on phytate phosphorus hydrolysis and total phosphorus retention of feed ingredients as determined with broilers and laying hens. Poultry Science, 78: 1151-1157.

Lim, H.S., Namkung, H. and Paik, L K. 2003. Effects of phytase supplementation on the performance, egg quality and phosphorus excretion of laying hens fed different levels of dietary calcium and non phytate phosphorus. Poultry Science, 82: 92-99.

Liu, B.L., Rafiq, A., Tzeng, Y.M. and Rob, A. 1998. The induction and characterization of phytase and beyond. Enzyme Microbiology Technology, 22: 415-424.

Liu, N., Liu, G.H., Li, F.D., Sands, J.S. Zhang, S. Zheng A.J. and Ru, Y.J. 2007. Efficacy of phytases on egg production and nutrient digestibility in layers fed reduced phosphorus diets. Poultry Science, 86: 2337-2342.

Lucky, N.J. 2010. Effects of dietary exogenous phytase on laying performance at advance stage. M.S. Thesis, Department of Poultry Science, Bangladesh Agricultural University, Mymensingh-2202, Bangladesh.

Mabe, I., Rapp, C., Bain, M.M. and Nys, Y. 2003. Supplementation of a corn $\neg$ soybean meal diet with manganese, copper, and zinc from organic or inorganic sources improves eggshell quality in aged laying hens. Poultry Science, 82: 1903-1913.

Maenz, D.D. and Classen, H.L. 1998. Phytase activity in the small intestinal brush border membrane of the chicken. Poultry Science, 77: $557-563$.

Nakano, T. Ikawa, N.I. and Ozimek. L. 2003. Chemical composition of chicken eggshell and shell membranes. Poultry Science, 82: 510-514.

Nezhad, Y.E. and Kandi, J.G.G. 2008. The effects of combination of ethylenediaminetetraacetic acid and microbial phytase on the egg quality characteristics in laying hens. Journal of Animal and Veterinary Advances, $7(2): 213-216$. 
Panda, A.K., Rama Rao, S.V., Raju, M.V.L.N. and Bhanja, S.K. 2005. Effect of microbial phytase on production performance of White Leghom layers fed on a diet low in non phytate phosphorus. British Poultry Science, 46(4): $464-469$.

Park, K.W., Rhee, A.R., Um, J.S. and Paik, I.K. 2009. Effect of dietary available phosphorus and organic acids on the performance and egg quality of laying hens. Applied Poultry Research, 18: 598-604.

Roland Sr. D.A. Sohail, S.S, and Bryant, M.M. 2003. Influence of dietary fat on economic returns of commercial Leghorns. Journal of Applied Poultry Research, 12: 356-361.

Roland, D.A., and Gordon. R.W. 1996. Metabolism and role of phosphorus, calcium and vitamin D3 in layer nutrition. Journal of Applied Poultry Research, 125 $\neg 136$.
Silversides, F.G., Scott, T.A., Korver, D.R. Afsharmanesh, M. and Hruby. M. 2006. A study on the interaction of xylanase and phytase enzymes in wheat - based diets fed to commercial white and brown egg laying hens. Poultry Science, 85: 297-305.

Um. J.S. and Paik. J.K. 1999. Effects of microbial phytase supplementation on egg production, eggshell quality and mineral retention of laying hens fed different levels of phosphorus. Poultry Science, 78: 75-79.

Van der Klis, J.D. Versteegh, H.A.J., Simons. P.C.M. and Kies, A.K. 1997. The efficacy of phytase in corn-soybean meal-based diets for laying hens. Poultry Science, 76: 1535-1542. 